\title{
Law Reform and Improving Asset Recovery in Indonesia: Contemporary Approach
}

\author{
Hendra Karianga \\ Faculty of Law, Khairun University \\ Jln. Batu Angus, Dufa-dufa, Kota Ternate, North Maluku, Indonesia
}

\begin{abstract}
Despite these significant efforts, the process of asset recovery remains complex and coordination among relevant agencies is challenging. The research is normative legal research by using statute, case, and conceptual approaches. The results show that Indonesia needs to strengthen its political will so that an anti-corruption agency can achieve long-term success. The position and duties of the Asset Recovery Center need to be restructured so that they can up-to-date in order to recover assets as an inseparable part of law enforcement carried out by the Attorney General Office of the Republic of Indonesia. The need for law reform based on the paradigm of attorney's authority by establishing a legal entity in the organizational structure. However, the public must first be informed of the problems of public corruption before they can demand change. Hence, an informed public is integral to the concept of strengthening political will.
\end{abstract}

Keywords: Asset Recovery; Corruption; Legal Structure; Law Reform

DOI: $10.7176 / \mathrm{JLPG} / 93-15$

Publication date: January $31^{\text {st }} 2020$

\section{Introduction}

Asset recovery remains high on the global agenda. Like other countries in the Southeast Asia region, Indonesia faces serious challenges due to corrupt practices and embezzlement of public assets, resulting in a staggering negative impact on its political, social, and economic development. Most stolen assets are spread out worldwide, demanding international cooperation. ${ }^{1}$ However, the Indonesian Government is dedicated to eradicating corruption. Two Presidential Instructions were introduced on the prevention and eradication of corruption, including an action plan for asset recovery.

Hence, the attorney of the Republic of Indonesia as a law enforcement agency is a State institution authorized to handle and resolve cases that are entrusted to it. The cases that are entrusted to it are criminal case since the commencement of investigations to the execution (center of criminal justice system) and civil case in position as State' lawyers representing the State based on a special power of attorney. Therefore, in essence the attorney of the Republic of Indonesia conducts his duties as law enforcer through a process of law enforcement (due process of law) in which implied legal protection both to citizens and State assets.

Law enforcement and recovery of State assets due to a crime are two sides of a coin that cannot be separated in eradicating specific criminal offense in the form of corruption. In common, corruption related to State assets is sometimes saved abroad by offenders to avoid the law enforcement officers, specifically the attorney's enforcer of the Republic of Indonesia. Sometimes State assets saved abroad as a consequence of a corruption offense experience obstacles in its return. It is because cross-jurisdiction that often creates obstacles in its implementation and impact to the authority of the government, particularly the authority of law enforcement in Indonesia. Various formal efforts were conducted by the Government of the Republic of Indonesia so that assets can be returned to the State treasury, therefore stipulating Act No. 1 of 2006 concerning Mutual Legal Assistance in Criminal Cases.

At present, it is known that the amount of Indonesian money deposited in banks in Singapore is getting bigger. Funds of wealthy Indonesians individually as much as US\$ 150 billion, or around Rp. 1.500 trillion, excludes corporate savings, if added to corporate customers, it reaches around US\$ 300 billion or over Rp 3.000 trillion, ${ }^{2}$ and the government has a discourse on a tax amnesty policy to increase tax revenue, by expecting to bring back the thousands of trillions rupiah that deposited abroad by Indonesian citizen. The government has a number of fundamental considerations for implementing the policy, the first is for the imposition of tax amnesty in the short term will provide significant tax additions, the second is in the long term, it can strengthen the tax base in Indonesia, and the third is the participation of Indonesian in the Automatic Exchange of Information program in which it is believed to be able to help implement tax amnesty policies in Indonesia. By this program, in 2017 countries can exchange information automatically. ${ }^{3}$

The policy of tax amnesty will causes a lot of controversy because it is counterproductive to other

\footnotetext{
${ }^{1}$ International Development Law Organization (IDLO). 2018. Eradicating Corruption in Indonesia: Improving Asset Recovery. Available online at: https://bit.ly/2Rdhond Accessed on 3 Nov, 2019.

${ }^{2}$ Kompas. President Director of PT Bank Mandiri Budi G Sadikin Tuesday, 26 August 2014.

${ }^{3}$ Director of Service, Counseling and Public Relation of the Directorate General of Taxation, The Indonesian Ministry of Finance.
} 
regulations, because in this tax amnesty it is also possible the elimination of other crimes such as money laundering, narcotics, corruption, illegal fishing, illegal logging and illegal mining. The existence of the Asset Recovery Center in the Attorney General of the Republic of Indonesia gives hope to all Indonesian people that it is able to recover State assets and these assets can be useful for development in order to achieve the State' goals. But in reality, the existence of the Asset Recovery Center still poses problems. One of them is the Asset Recovery Center Team is not maximal in the effort to recover corrupt assets and State' losses which are followed-up by conducting an audit of the Asset Recovery Center Team. Also, the audit is to ascertain whether the auction process for corrupt assets that has been conducted by the Asset Recovery Center has succeeded in getting the highest price of money or not. However, as it turns out into practice, so far the auction process by the Asset Recovery Center has been conducted in a closed and less transparent manner.

In addition, asset management is not-integrated. In each stage the criminal procedure (investigation, prosecution and execution) is handled by different technical/operational units so that assets are prone to lost, damaged, reduced, and moved illegally, lost economic value, especially during the transition from one stage to stage other. Technical/operational work units are too overburdened with juridical technical handling and case administration so they do not have enough time to handle the assets related to the case plus they do not have enough capacity or capability to handle non-conventional assets such as ships, aircraft, valuables or assets that require special expertise or handling. For this reason, to produce or create an asset recovery institution that can accommodate the aspirations or desires of the State so that assets are used for the greatest prosperity of the people as mandated by the Constitution.

\section{The Essence of the Establishment of the Asset Recovery Center}

Indonesia has a deep-rooted history with public corruption, and its detrimental effects necessitate an effective solution to curb this endemic problem. Public corruption is defined as the "abuse of public power for private gain." Indonesia's problem with public corruption is significant because it is "a tragic form of regressive taxation. The poor pay higher prices because of all the monopolies, and they have to pay off government officials for everything they need." Apart from the economic costs, public corruption has a damaging social cost. As the United Nations ("UN") states, public corruption "undermin[es] the institutions and values of democracy, ethical values and justice, and jeopardize[s] sustainable development and the rule of law."2

The Attorney of the Republic of Indonesia as a non-ministerial State government agency that carries out State power in the field of prosecution and other tasks provided by law must be free from the influence of any party power. This is intended so that the Attorney of the Republic of Indonesia can exercise State power related to judicial power in the context of law enforcement. Related to the prosecution and implementation of court decisions that have legal force remain the State power granted attributively by the 1945 Constitution.

The Attorney General Office as an inseparable part of the Attorney of the Republic of Indonesia can establishes an institution as an implementation of other authorities granted by law. The institution that was established was the Asset Recovery within the scope of the Attorney General Office. The Asset Recovery as established in order to safe State' assets originating from State' property, confiscated goods, booty, and found items. Protection of State assets is an inseparable part of the State obligation to protect the entire Indonesian nation and all of Indonesia's blood.

Today, there are 2 (two) mechanisms for asset confiscation in Indonesia that are taken in the process of recovering assets as result of corruption. The first, by tracking, the assets that have been successfully tracked and found are frozen. The second, the assets that have been frozen are confiscated and seized by the competent authority of the country where the assets are stored, and then returned to the place where the assets originated. ${ }^{3}$

Asset Recovery starts from the search, seizure, until the process of auctioning assets (for criminal cases) and inventory of requested assets, confiscation and execution (for civil cases) to return the results to the State in the context of saving State finances so that in this case the assets recovery will relating to various institutions and agencies in an integrated and dynamic manner.

In essence, the sociological consideration emphasizes authority in the framework of law enforcement on asset recovery. Therefore, in order to exercise full authority and integrated manner, the Attorney of the Republic of Indonesia seeks to save the State' wealth in the form of asset recovery. Asset recovery is essentially restoring State finances, because these assets are an inseparable part of State finances. The law is enforced, namely criminal law, civil law, or State administrative law at the time of asset recovery. It shows that asset recovery aims to secure assets from disturbances, both juridical and non-juridical, such as earthquakes, fires, or tsunamis that can damage assets.

\footnotetext{
${ }^{1}$ Alvaro Cuervo-Cazurra, Who Cares About Corruption?, 37 J. Int'1 Bus. Stud. 803, 807 (2006).

U.N. Office on Drugs and Crime, UNODC South Eastern Europe on Corruption, http://www.unodc.org/southeasterneurope/en/Corruption.html (last visited Jan. 29, 2011).

${ }^{3}$ Nyoman Serikat PJ, Tindak Pidana Korupsi, Kolusi, dan Nepotisme di Indonesia, Badan penerbit Universitas Diponegoro, Semarang, 2005, p. 6
} 
The essence in the establishment of the Asset Recovery Center aims to make the State' assets can be used to the prosperity of the people. Because the prosperity of the Indonesian people is the responsibility of the State carried out by the President of the Republic of Indonesia as the highest authority in Indonesia. The establishment of the Asset Recovery Center is essentially to protect and manage State assets for the greatest prosperity of the people.

\section{An Ideal Concept of the Institutional of Asset Recovery in the Future}

The institutional of asset recovery in the future is expected to be in the form of a commission or agency that exercises authority to recover assets. By considering that the Asset Recovery Center is currently in the position of second echelon in the organization and work procedures of the Attorney General Office of the Republic of Indonesia. It shows that the Asset Recovery Center only exercises asset recovery as an inseparable part of criminal law enforcement, civil law, or State administrative law.

The existence of the agency as an institutional of asset recovery in the future is the authority of the President of the Republic of Indonesia to exercise governmental power derived from Article 4 paragraph (1) of the 1945 Constitution of the Republic of Indonesia which confirms that the President of the Republic of Indonesia holds the power of government governing the constitution. Thus, the President of the Republic of Indonesia has the authority to stipulate a Presidential Regulation in the context of implementing State government.

If the institutional of asset recovery in the form of "agency" in the future means outside the organizational structure and work procedures of the Attorney General Office of the Republic of Indonesia. Therefore, the institutional of asset recovery in the future is in the position of "Non-Ministerial Government Institutions" whose duties to exercise asset recovery, including protection. This is no different from the "Maritime Security Agency" which is outside the organizational structure and work procedures of the Indonesian Navy. It is more efficient and as a combination of human resources with expertise and performance is inseparable in the marine field.

The institutional of asset recovery in the future, both in the form of "commission" or "agency" must be equipped with the authority to recover assets. Essentially, in the future the institutional of asset recovery is a position that has authority to be implemented. The exercise of authority is conducted by the appointed office holders or chosen based on transparency and accountable.

It is different, if the institution of asset recovery in the future is established in the form of a body/agency; it means that the authority is independent of the policy of the Attorney General of the Republic of Indonesia. The legal consequence that arises is that the body as an institution for asset recovery in the future is outside the organization and work procedures of the Attorney General Office of the Republic of Indonesia. In a sense, the body or agency as a Non-Ministerial Government Institution has an autonomous nature in the context of asset recovery. Therefore, the authority of the agency as a Non-Ministerial Government Institution originates from the policy of the President of the Republic of Indonesia in the context of law enforcement on asset recovery.

The presence of a body as an institution of asset recovery in the future as a Non-Ministerial Ministry Institution to assist the President of the Republic of Indonesia in implementing State governance in the field of asset recovery. In a sense, asset recovery is not the authority of the Attorney General Office of the Republic of Indonesia but has been transferred to an agency as a Non-Ministerial Government Institution must be equipped with the authority so that it is able to coincide with the criminal law, civil law, state administrative law in the context of law enforcement in the field of asset recovery.

The institutional of asset recovery in the future can be determined in the form of a commission or agency that conducting asset recovery. Essentially, the recovery of these assets sourced from the authority they have. The exercise of authority must be held accountable to the authorities. If determined in the form of a commission, it means that the responsibility is directed at the Attorney General Office of the Republic of Indonesia. Because the commission was allowed to be established as regulated in Article 38 of the Republic of Indonesia Act No. 16 of 2004 concerning the Attorney General Office of the Republic of Indonesia. Therefore, the commission is within the organization and work procedures of the Attorney General Office of the Republic of Indonesia.

It is different, if the institutional of asset recovery in the future is determined in the form of an agency, it means that its position as a Non-Ministerial Government Institution. By considering that its existence is outside the organization and work procedures of the Attorney General Office of the Republic of Indonesia so that the accountability is addressed to the President of the Republic of Indonesia. In other words, the exercise of its authority must be accountable to the President of the Republic of Indonesia. Liability is an obligation that must be done. Liability is essentially a legal act within the framework of exercising the authority given.

The liability that is carried out is the institutional liability not individual. Although institutional liability is still represented by the party authorized for it. Thus, the institutional of asset recovery in the future as a body/agency, in essence must be represented by the person who leads an institution. This is done in order to improve the quality of the attorney's performance to recover assets in the future. By considering that the commission is essentially an inseparable part of the organization and work procedures of the Attorney General 
Office in the future. Thus, in the future the liability of asset recovery commission is directed at the Attorney General of the Republic of Indonesia.

For this reason, Indonesia needs to strengthen its political will so that an anti-corruption agency can achieve long-term success. A lack of political will may be overcome by citizens demanding action from public officials, forcing the officials to effectuate reforms directed at curbing public corruption. However, the public must first be informed of the problems of public corruption before they can demand change. ${ }^{1}$ Hence, an informed public is integral to the concept of strengthening political will.

\section{Conclusion}

Due to Indonesia's problems in combating public corruption, the Indonesian government decided it was necessary to adopt a stronger anti-corruption strategy. The position and duties of the Asset Recovery Center need to be re-structured so that they can up-to-date in order to recover assets as an inseparable part of law enforcement carried out by the Attorney General Office of the Republic of Indonesia. The need for law reform based on the paradigm of attorney's authority by establishing a legal entity in the organizational structure of the Attorney General Office of the Republic of Indonesia that manages an integrated asset recovery system through handling and resolving extraordinary law enforcement based on the establishment of special laws and regulations concerning the management of State asset recovery as a form of optimizing the recovery of State assets in the context of fulfilling legal objectives to achieve the benefits and prosperity of the peoples.

\section{References}

Alvaro Cuervo-Cazurra, Who Cares About Corruption?, 37 J. Int'l Bus. Stud. 803, 807 (2006)

Asep N. Mulyana, 2016. Dimensi Koruptif Kebijakan (Pejabat) Publik, Jakarta: Madju Press.

Hendrik Dengah, M. Syukri Akub, Slamet Sampurno, Syamsuddin Muchtar. (2019). 'Hand Catch Operation' on Corruption Crimes: The Case of the KPK in Indonesia, Journal of Law, Policy and Globalization, Vol. 81, pp: 32

International Development Law Organization (IDLO). 2018. Eradicating Corruption in Indonesia: Improving Asset Recovery. Available online at: https://bit.ly/2Rdhond Accessed on 3 Nov, 2019.

Joanna MacMillan. 2011. Reformasi and Public Corruption: Why Indonesia's Anti-Corruption Agency Strategy Should Be Reformed to Effectively Combat Public Corruption, Emory International Law Review, Vol 25 Issue 1: 587-630

Kimberly Ann Elliot. 1999. Korupsi dan Ekonomi Dunia. Jakarta: Yayasan Obor Indonesia.

Nyoman Serikat PJ, Tindak Pidana Korupsi, Kolusi, dan Nepotisme di Indonesia, Badan penerbit Universitas Diponegoro, Semarang, 2005, p. 6

Purwanti, A., Ispriyarso, B., \& Wijaningsih, D. (2018). Strategizing Local Regulation On Women Representation in Village Policy-Making as A Realization of Sustainable Development Goals: A Study in Semarang Regency. Journal of Social Studies Education Research, 9(4), 319-333.

Rohim. 2008. Modus Operandi Tindak Pidana Korupsi. Cimanggis Depok: Pena Mukti Media.

Sugeng Purnomo, Muhadar, Farida Patittingi, and M. Said Karim. (2018). Corruption Crime in Lending to the Government Banks: A Challenge in Criminal Law, Journal of Law, Policy and Globalization, Vol. 80.

U.N. Office on Drugs and Crime, UNODC South Eastern Europe on Corruption, http://www.unodc.org/southeasterneurope/en/Corruption.html (last visited Jan. 29, 2011).

\footnotetext{
${ }^{1}$ Joanna MacMillan. 2011. Reformasi and Public Corruption: Why Indonesia's Anti-Corruption Agency Strategy Should Be Reformed to Effectively Combat Public Corruption, Emory International Law Review, Vol 25 Issue 1: 587-630
} 